Leading by example, saving energy and taxpayer dollars in federal facilities

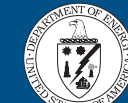
Energy Efficiency and Renewable Energy Bringing you a prosperous future where energy is clean, abundant, reliable, and affordable

\title{
Federal Energy Efficiency through Utility Partnerships
}

\section{Overview}

The Department of Energy's Federal Energy Management Program (FEMP) works to reduce the cost and environmental impact of the Federal Government by advancing energy efficiency and water conservation, promoting the use of distributed and renewable energy, and improving utility management decisions at Federal sites. As the largest single energy consumer in the United States, the Federal Government has both a tremendous opportunity and a clear responsibility to "lead by example" with smart energy management.

While the government has made considerable progress improving its use of energy, much more can be done to save energy, promote the use of renewable technologies, and reduce our dependence on foreign oil. Energy management is one of the most challenging tasks facing today's Federal facility manager. Luckily, Federal agencies do not need to meet this challenge alone.

\section{FEMP's Federal Utility Program actively} fosters partnerships between Federal agencies and their facilities with local utilities. The purpose of the partnerships is to jointly plan and implement energy efficiency, water conservation, and renewable energy projects at Federal facilities nationwide. Due to current budget constraints, rising energy costs, and increased requirements to reduce energy and water consumption in Federal facilities, energy managers are challenged to identify the most costeffective measures for implementing necessary capital improvements. Recognizing these and other issues such as increased demand for energy and growing environmental concerns, local utility companies are significantly expanding the range of energy-saving services and incentive programs they offer their customers.

FEMP's Utility Program facilitates Utility Partnerships and uses Utility Energy Services Contracts (UESCs) to help Federal agencies navigate through the wide array of energy services that utility companies offer Federal customers. The Utility Program also works to encourage local utility companies to assist agencies in meeting their energy efficiency, renewable energy, and water conservation goals.

\section{Background}

The Federal Government is the nation's largest utility customer, spending more than $\$ 5.8$ billion annually. Along with this large energy bill comes the responsibility to be a leader in managing and using energy wisely. The Energy Policy Act of 2005 (EPACT) and Executive Order 13423 require Federal agencies to reduce their energy consumption by 30 percent and establishes additional goals for water conservation, energy management, and renewable energy use. To achieve these goals, the Federal sector will need to invest at least $\$ 4$ billion in public and private funds in their facilities, along with learning how to 
operate and maintain their facilities at an optimal level. Local utilities can provide agencies with the financing and technical expertise to meet this challenge.

\section{Utility Energy Management Services}

No matter which contract vehicle agencies choose to make the necessary investments in their facilities, facility energy mangers should take the time to learn about the services their local utility company can provide. Often, services offered by local utilities are available at low or no cost to the customer and are funded by fees included in utility rates. FEMP has surveyed its utility partners to identify no-cost and low-cost services typically provided to Federal customers. The list includes:

- Rebates/Incentives

- Energy audits

- Rate analysis

- Technical assistance and/or design review

- Building commissioning

- Metering

- Web access to utility account data

- Power quality and reliability assistance

In fact, over $\$ 1$ billion in incentives and rebates are available each year from state and local utility programs. To obtain a state-by-state listing of energy efficiency incentives, rebates, and demand-response programs available to Federal facilities, go to: www.eere.energy.gov/femp.

Additionally, FEMP can provide direct assistance to agencies wishing to participate in local demand-response programs or access utility rebate and incentive programs.

\section{The Federal Utility Partnership Working Group (FUPWG):}

FUPWG was established in 1994 to partner Federal agencies with utilities to exchange information and lessons learned and to identify opportunities to improve the efficiency of Federal buildings. Working group members develop strategies to help implement cost-effective energy efficiency, water conservation, and renewable energy projects in Federal facilities. The common interest of FUPWG's Federal and utility members is to reduce the cost of government through Utility Energy Service Contracts (UESCs) and incentive programs at Federal sites.

FUPWG conducts two working group meetings per year; each meeting is hosted by a member utility. FEMP also works with utilities to hold strategic partnership meetings to educate Federal customers about the range of services offered by the utilities.

\section{Utility Energy Services Contracts (UESCs)}

UESCs provide an easy way for Federal agencies to contract for the broad spectrum of energy management services offered by their local utility. Federal agencies may use either appropriated funds or secure third party project financing through the utility when implementing UESCs. In fact, implementing projects through UESCs continues to be a major force behind how many Federal facilities are meeting their energy management goals. To date, Federal agencies have used UESCs to invest over \$1.6 billion in their facilities.
A Strong Energy Portfolio for a Strong America

Energy efficiency and clean, renewable energy will mean a stronger economy, cleaner environment, and greater energy independence for America. Working with a wide array of state, community, industry, and university partners, the U.S. Department of Energy's Office of Energy Efficiency and Renewable Energy invests in a diverse portfolio of energy technologies.

For More Information on the FEMP Utility Program, please contact:

David McAndrew

Utility Project Manager 202-586-7722

david.mcandrew@ee.doe.gov

Karen Thomas

UESC Project Assistance

202-646-5223

karen_thomas@nrel.gov

Phil Coleman

Demand Response, Rebates, and Incentives

610-604-0170

pecoleman@lbl.gov

Leslie Nicholls

FUPWG Coordinator

Inicholls@energetics.com

202-479-2748, extension 128

www.eere.energy.gov/femp

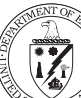

Energy Efficiency and Renewable Energy

Bringing you a prosperous future where energy is clean, abundant, reliable, and affordable

EERE Information Center

1-877-EERE-INF or 1-877-337-3463

www.eere.energy.gov/

Produced for the U.S. Department of Energy by the National Renewable Energy Laboratory, a DOE national laboratory.

DOE/G0-102007-2456

August 2007 